\title{
Discours
}

Revue de linguistique, psycholinguistique et

informatique. A journal of linguistics, psycholinguistics and computational linguistics

28 | 2021

Varia

\section{Subordination in Italian and English: Implications for Second Language Acquisition}

Patrizia Giuliano and Simona Anastasio

\section{OpenEdition}

\section{Journals}

\section{Electronic version}

URL: https://journals.openedition.org/discours/11434

DOI: 10.4000/discours.11434

ISSN: 1963-1723

Publisher:

Laboratoire LATTICE, Presses universitaires de Caen

\section{Electronic reference}

Patrizia Giuliano and Simona Anastasio, "Subordination in Italian and English: Implications for Second

Language Acquisition", Discours [Online], 28 | 2021, Online since 13 October 2021, connection on 15

October 2021. URL: http://journals.openedition.org/discours/11434 ; DOI: https://doi.org/10.4000/ discours. 11434 

Revue de linguistique, psycholinguistique et informatique

\section{Subordination in Italian and English: \\ Implications for Second Language Acquisition}

\section{Patrizia Giuliano}

Dipartimento di Studi Umanistici

Università degli Studi di Napoli - Federico II

\section{Simona Anastasio}

Structures formelles du Langage - UMR 7023

CNRS, Université Vincennes-Saint-Denis - Paris 8

\section{Patrizia Giuliano, Simona Anastasio, « Subordination in Italian and English: Implications for Second Language} Acquisition», Discours [En ligne], 28 | 2021, mis en ligne le 13 octobre 2021.

URL: http://journals.openedition.org/discours/11434

Titre du numéro: Varia

Coordination: Benjamin Fagard \& Mathilde Salles

Date de réception de l'article: 20/12/2020

Date d'acceptation de l'article: 15/04/2021 



\title{
Subordination in Italian and English: Implications for Second Language Acquisition ${ }^{1}$
}

\author{
Patrizia Giuliano \\ Dipartimento di Studi Umanistici \\ Università degli Studi di Napoli - Federico II \\ Simona Anastasio \\ Structures formelles du Langage - UMR 7023 \\ CNRS, Université Vincennes-Saint-Denis - Paris 8
}

\begin{abstract}
Our study focuses on morpho-syntactic complexity, trying to identify the specific subordinated modalities of organizing and packaging information in a narration. This purpose will be achieved by combining the morpho-syntactic analysis with the type of contents that subordinate clauses convey with respect to the informational flux of textual structure (foreground vs. background alternation). A functionalist and enunciative framework is adopted. The following questions will be addressed: (1) which types of morpho-syntactic structures - main or subordinated, finite or non finite - are exploited to convey the subordinated contents selected? (2) do the informants tend to hierarchize the expressed contents? (3) which types of semantic and/or logical components (temporality, causality, etc.) are selected to be narrated and highlighted through subordination? We shall demonstrate that only the interaction of several factors - core morphological facts, interactional and discourse habits - can exhaustively explain the textual perspectives observed in our L1 and L2 data, with interesting consequences for second language acquisition.
\end{abstract}

Keywords: subordination, narration, second language acquisition, English L2

\begin{tabular}{ll}
\multicolumn{2}{l}{ Abbreviations } \\
BG & background \\
FG & foreground \\
f.pl. & feminine plural \\
f.s. & feminine singular \\
m. cl. & main clauses \\
m.pl. & masculine plural \\
m.s & masculine singular \\
occ. & occurrence \\
RQ & research question(s) \\
sub. cl. & subordinate clauses
\end{tabular}

1. This paper was directed and written by Patrizia Giuliano, except paragraphs $\S 6$ and $\S 7.2$ which were written by Simona Anastasio. The latter studied L2 data. Both authors contributed to the conclusion. 


\section{Introduction}

Narrating is one of the most well known verbal activities that human beings engage in throughout their life and it is a common belief that, once we learn to do that in a language, it will be easy to translate our narrative ability into other languages. Is this belief false? We propose that while it is certainly true that there is a universal organizational scheme that is repeated across cultures (cf. for instance Propp, 1968; Adam, 1981, 1997; Labov, 1972, 1997), it is also true that the actualization of this scheme is not the same from one language and culture to another. Any narration - to be such - needs to be composed of some essential components which can not only vary according to the theory and the author (introduction and setting, triggering event, internal response, etc.), but the way these components are instantiated in a linguistic community can be different both with respect to the conceptual and the structural domains and regarding the communicative habits of a community.

Concerning the conceptual sphere, the domains involved in a narration (entities, time, space, modality) can be highlighted to different degrees depending on the preferred perspective that a linguistic community tends to select: French native speakers constantly focus on causality, chronological order is particularly stressed in German narrations, ongoingness is crucial for English native speakers, "all of a sudden” events are highlighted in Italian retellings, etc. (cf. Carroll \& Stutterheim, 2003; Carroll \& Lambert, 2006; Carroll et al., 2008a and b; Giuliano \& Anastasio, in press).

As far as structural complexity is concerned, the way of expressing it obviously differs according to the grammar of each language, but we propose that the differences with respect to the degree of complexity that each community tends to select can also depend on different patterns of language and discourse use. Linguistic complexity has received a certain amount of attention in comparative and acquisitional linguistics (cf. for English, the above-mentioned studies; for Italian, Chini, 2003, 2005, 2008) but research on the topic is still relatively scarce.

Enunciative and interactional habits, finally, can also play a significant role in the manner of shaping a narration, even though very few authors have dedicated attention to this aspect so far (cf., nevertheless, Giuliano \& Di Maio, 2007; Giuliano \& Musto, 2016, 2018).

In the present paper we will take as our point of reference the concept that Givón (1995) and Givón and Shibatani (2009) proposed for linguistic complexity and the way it interweaves with the notion of (morphological) finiteness (cf. Givón, 1995; but also Klein, 2006; Klein \& Li, 2009) ${ }^{2}$. Specifically for the concept of

2. Finiteness is generally associated with tense, aspect, person and modality when expressed through verb morphology; nevertheless, finiteness can also be expressed through lexical means such as temporal, aspectual and modal adverbs and personal pronouns, as happens in isolating languages. 
subordination we will refer to Cristofaro (2003). Concretely, we will apply these notions to English and Italian native data and to acquisitional data in English L2 with a focus on subordination. For the non-native data, we will question whether the morpho-syntactic structures that learners adopt match those of the target language or are still influenced by the L1 textual perspective.

\section{Theoretical framework}

Our theoretical framework is functionalist and enunciative. For functionalism we draw mainly on Givón's work (above all Givón, 1995; Givón \& Shibatani, 2009) and the textual acquisitional approach of Carroll, Lambert and Stutterheim (cf. studies cited in part 1, among others). For the enunciative dimension ${ }^{3}$, we will refer to Culioli (1995) and Adamczewski (2002).

The notion of linguistic complexity, as it is used by Givón, is crucially linked to that of markedness. To distinguish a marked structure from an unmarked one, the author proposes three criteria (Givón, 1995: 28): (a) frequency: the marked structure is less frequent (and consequently more salient in cognitive terms) with respect to the corresponding unmarked structure; (b) cognitive complexity: the marked structure is heavier to process from a cognitive viewpoint than the corresponding unmarked one; (c) structural complexity: the marked structure tends to be linguistically more complex than the unmarked one. The declarative, affirmative and agentive clause is assumed to be the prototypical structure of predication, namely the most common and semantically most transparent predication found in natural communication: because of that, it is also the least marked. Any deviation from this basic structure will involve a process of complexification, which in turn can be expressed in different ways: by recursive and embedding complexity and by condensing complexity (cf. also Havu \& Pierrard, 2012). The first type involves "[...] increased hierarchic organization, that is an increase in the number of hierarchic levels within a system" (Givón \& Shibatani, 2009: 2). The second type of complexity is explained by Havu and Pierrard (2012) as a process which involves a weakening of the prototypical predicative structure, namely a reduction of the predicative integrity of one event with respect to another one by suppression of a subordinator and/or loss of morphological finiteness, and consequently of autonomy. Relative embedded clauses are an example of recursive complexity; non finite clauses exemplify condensing complexity. Our concern being subordination, we will consider as subordinated any conceptual structure that is cognitively dependent on another structure independently from its morpho-syntactic peculiarities (overt/implicit connector, finite/non finite verb), in agreement with a functionalist-typological perspective (Cristofaro, 2003).

3. We do not refer to any generativist work on linguistic - especially syntactic - complexity, since our study did not draw on any work within this framework. 
We will implement the notion of linguistic complexity in the textual framework developed over the last two decades in the field of European second language acquisition (cf. references above). This framework has shown that advanced L2 learners master the grammar of the target language at utterance level but not at discourse level, since their way of establishing anaphoric linkage and textual cohesion still reflects their mother tongue perspective-taking ${ }^{4}$. These studies will be our reference point along with the Quaestio model of textual analysis by Stutterheim and Klein (1989) and Klein and Stutterheim (1991), according to which a text is wholly shaped and informationally organized with respect to an unconscious question that individuals have learnt to formulate since early childhood. The prototypical question, or Quaestio, concerning a narrative text is what happened to the protagonist in time $X$ ?, where the event is the information segment to be specified, or the focus, and the protagonist and the time span are the segments in topic. But the Quaestio is influenced by the formal and conceptual patterns a certain language has available (core grammatical features), which explains the possibility for individuals of different native languages to conceive, for the same type of text, relatively different Quaestiones. For instance, for English, the appropriate Quaestio could be what is bappening to the protagonist now?, in which the deictic perspective is emphasized; for German, a Quaestio such as what happened to $P$ after event $X$ seems more pertinent, and so on. This internal question dictates the discourse principles that coherence and cohesion are based on. The direct answers to the Quaestio form the foreground or main structure of a narration; information other than these answers, such as opinions, explanations, is said to form the background or side structures. As a result, the foreground is strictly dictated by a chronological order, whereas the background can consist of information of any kind (causal, temporal, etc.) including flashbacks. The Quaestio theory can be easily combined with Slobin's thinking for speaking hypothesis (cf. part 4.1), since the Quaestio itself forges the way in which thoughts must be assembled when individuals express themselves in words.

Concerning the enunciative dimension we will interpret our results by taking the enunciator as the absolute origin of locative operations, since every enunciative operation is located with respect to him/her. As a consequence, the cohesive perspective that an enunciator selects while producing an oral text is the result of his/her communicative needs with respect to a specific co-enunciator and cultural content, and not simply a selection of the most accessible linguistic means made available by one's mother tongue via the grammatical and lexical processes ${ }^{5}$. The centrality of the enunciator in the construction of an utterance is crucial in order to understand the functioning of a verbal language from the perspective proposed

4. The concept of perspective owes a lot to the meaning that Dan I. Slobin has provided in his various studies on the thinking for speaking hypothesis since the late eighties (cf., e.g., Slobin, 1991, 1996, 2003): speakers of a given language exploit different rhetorical styles that reflect their different ways of looking at reality when they have to talk about it.

5. This is the main point of contrast between the enunciative perspective and the Quaestio theory. 
by enunciative linguistics. The linguistic activity by the enunciator is seen as being mainly unconscious: utterances are the result of an interior work which necessarily precedes the time of utterance. So the enunciator is the "architect" who plans and builds the utterance and who shows his communicative intention by freely choosing among the different possible strategies that are available in a given language with respect to a specific textual genre, context and community (Adamczewski \& Gabilan, 1993). In the perspective of enunciative grammar, each grammatical element is an operator that makes it possible to instantiate some relationships (cognitive operations) with respect to the communicative context in which they are produced. If you put the enunciator at the center of the linguistic research, that necessarily leads to a change of perspective: grammar becomes the study of the expressive potentialities of the various operators that the enunciator uses and of the consequences - on the level of expression/interpretation - of each choice that he/she makes. Such a grammar focuses on the speakers and the relationships between them but also on the relationships between the enunciator and the topics that he/she is talking about, the utterances and the words that he/she employs, and above all the language and the extra-linguistic world (cf. Musto, 2018).

Functionalist and enunciative approaches are, in our perspective, essential to each other since both are necessary for an exhaustive comprehension of human language in its concrete usage within a culturally specific community. Speakers of different communities may in fact follow different principles of discourse collaboration, that Gumperz and Levinson (1996: 327 and 331) condense in the principle of joint salience:

For the participants in a co-ordination problem, the optimal co-ordination device is the one that is most salient in the participants' current common ground [...].

How you and I co-ordinate, with or without collaboration, depends on the information we believe we share at that moment. But how? For that, we need to understand what two people's common ground consists of.

The same authors wonder (Gumperz \& Levinson, 1996: 374 and 383):

$[\ldots]$ to what extent are the discursive processes, by which interpretive frames are invoked and shared interpretations negotiated, themselves linguistically and culturally variable?

[...] So the variability in contextualization convention is culturally significant.

So, we support the idea that each community of speakers selects specific mechanisms of referential interpretation and preferred patterns of language use in a given discourse context. Textuality is both central and variable across languages and cultures. As Culioli (1995: 20-21) put it: "I apprehend language only through texts. Given these texts in a language, how does one represent phenomena within this framework, or are these phenomena heterogeneous?". As a result, we are convinced that grammatical rules alone cannot exhaustively explain the complexity of real language use in a specific context with respect to a given discourse genre. 


\section{Subordination in Italian and English: reflections and terminology}

Some preliminary considerations about the languages concerned, Italian and English, are necessary in order to make our research questions clear for the reader.

For Italian, it is possible to hypothesize that a core typological feature of this language, namely the strong morphology, could favor the structural mechanisms commented on in part 2: condensation, recursion and syntactic embedding in general $^{6}$, by virtue of the greater informativeness that it conveys. The strong verb morphology could, for instance, allow a more frequent recourse to subordinate clauses expressed by the Participio Passato, which in Italian is inflected both for number and gender (ex. comprat-o/m.s., -a/f.s., -i/m.pl., -e/f.pl. = Engl. bought), and that can refer back to an antecedent, be it a subject or an object (cf. [1]).

[1] Mario ha comprato una casa situata su di una collina coltivata a girasoli

Mario has bought a house situated/f.s. on a hill cultivated/f.s. with sunflowers

'Mario has bought a house situated on a hill where sunflowers are cultivated'

In [1], the first Participio Passato, situata ("situated"), explicitly agrees in gender and number with casa; the second one, coltivata ("grown"), agrees in gender and number with collina. Tense, aspect and modality are implicit in both cases; the reference is back to the immediately preceding object (casa and collina). Passage [1] can be translated into English but some changes seem necessary, since native speakers of English would not select one Past Participle after the other one, probably for their very condensed character: no explicit information about finiteness is actually obtainable from the English Past (or -ed) Participle (cf. Giuliano \& Anastasio, in press). Conversely, the rich morphology of Italian provides this information in such a way that the Participio Passato is more transparent than the English Past Participle, since the former conveys some information about finiteness (person and gender) that the latter cannot.

Concerning the Italian Gerundio, its English counterpart belongs to the domain of Participles. More specifically, the Italian Gerundio normally corresponds to the English Adverbial Participle (cf., for instance, Quirk et al., 1985; Granger, 1997) ${ }^{7}$. For both the Italian Gerundio and the English Adverbial Participle, finiteness is totally implicit (cf. tornando "going back" in [2]):

[2] Giulio fa la spesa tornando a casa

'Giulio does shopping going back home'

6. As is well known, recursion is the repetition of the same rule such as a chain of relative clauses. In this study we will also consider non recursive embedding as an expression of linguistic complexity.

7. The English Gerund corresponds, as is well known, to nominalizations as in "I enjoy spending my holidays with them". The Adverbial Participle, conversely, can take on temporal, causal, conditional, etc. meanings. 
For Italian, the recourse to the Gerundio could be strengthened by a typological feature typical of this language: the null subject property. The implicit subject of the Gerundio is in fact, normally, coreferential with the subject of the preceding finite clause ${ }^{8}$.

Concerning the Participio Presente and the (-ing) Postmodifying Participle ${ }^{9}$, their use in the two languages is very different. While in English it frequently replaces explicit relative subordinates (reduced relative clauses in the terminology of Granger [1997]) ${ }^{10}$, in Italian (where most Participi Presenti have become adjectives) this is not the case, except for very few forms such as proveniente ("coming-from") and concernente ("concerning").

Another consideration concerns recursion and syntactic embedding in general. Firstly, we can wonder whether the richness of morphology can be at the origin of the deep embedding of subordinate clauses observed for Italian by Giuliano (2013) in a comparison between Italian and French. Counting on the transparency of rich finite forms and Participi Passati, the Italian native speaker could be encouraged to embed clauses to a deeper degree with respect to a speaker having English - a weaker morphology language than French - as L1. From a communicative viewpoint, we can hypothesize that the degree of embedding and recursion is less risky for an Italian speaker thanks to the repetition of information about finiteness conveyed by each verb form in the hierarchical embedding. In other words, we propose that deep embedding - even though ascertained to be heavier to process from a cognitive viewpoint - could be favored in languages with rich verb morphology.

\section{The study}

\subsection{Purposes of the study}

In the present study we will focus on morpho-syntactic complexity, trying to identify the specific subordinated modalities of organizing and packaging information in a narration. The finite/non finite distinction will guide our analysis together with the functions that clauses perform in traditional grammar (adverbial, complement and relative) and their sub-distinctions (adverbial = cause, time, purpose, manner, instrument, comparison; complement $=$ object and subject). The context will be responsible for the semantic interpretation of clauses, both finite and non finite. The

8. For a comment of this point, cf. part 5.1; cf. also the results by Natale (2013) in which a comparison between Italian and French is presented.

9. In the terminology of Granger (1997), Postmodifying Participles (with -ed or -ing) work as postmodifiers to nouns and pronouns (ex.s from Granger [1997: 187]: a report written by my colleague appeared last week; this is a liquid with a taste resembling that of soapy water).

10. Granger (1997) points out that English (adverbial and postmodifying) Participles are much more frequent in academic writing than in the spoken language. For Italian, a greater frequency of Participi in the written language is also ascertained but only for the Participio Passato, of course. 
purpose of the analysis will be reached by combining the criteria just presented with the informational flux of textual structure (foreground vs. background alternation).

From the discussion introduced in part 3 , we have formulated the following research questions, for both learner and native-speaker groups:

1. which types of morpho-syntactic structures - finite or non finite - are exploited to convey the subordinated contents selected?

2. which types of semantic content and logical structure (temporality, causality...; object, subject..., relative) are selected to be narrated and highlighted through subordination?

3. do the informants tend to hierarchize the subordinated contents expressed? Specifically for learners, we will wonder:

4. are they influenced by their L1 perspective?

The combination of specific contents with specific structures will create a language specific perspective (cf. Slobin, 1991, 1996, 2003).

With respect to the first question and to non finite expressions, we will especially investigate Italian and English participial clauses and Italian Gerundio clauses, since mastering them can be much more problematic than infinitives. All three questions above will be answered with respect to Italian and English native data as well as to acquisitional data in English L2. The comparison between Italian and English as L1s will lead us to consider the possible similar or different perspectives that native speakers of these two languages select when executing the same oral task (for which, cf. part 4.2). From these considerations it will be possible to draw typological conclusions, given the different nature of the two languages in question (English is more an isolating than an inflectional language; Italian is a very inflectional language).

The acquisitional data, instead, will let us compare the greater or lesser distance of learners' narrations from those of native speakers. Lastly, on the basis of the L2 results we will consider some possible implications for second language acquisition (and partly also learning) of subordination.

\subsection{The stimulus and the informants}

The stimulus that we used to collect our L1 and L2 data is a ten minute long film titled Quest, produced by T. Stellmach in 1997 and already used in studies about perspective in L1 and L2 (cf., for instance, Carroll \& Stutterheim, 2003; Carroll \& Lambert, 2006; Carroll et al., 2008b). Since in the past it was exploited very infrequently for Italian, our present study makes a comparison with other work possible.

The story is about a man made of sand moving through different worlds in order to search for water. The film opens up with the protagonist being in a sandy world 
from which he moves to a paper world and from there to a world made of rocks and finally to another one full of industrial machines. Each of these places involves several dangers for the sand man. The leitmotif during the passage from one world to another one is given by the sound of water dripping, which the protagonist continually tries to reach but never succeeds.

The stimulus was shown to our informants according to the same methodology followed by the authors above: first the informant watched the whole film; then he/she watched it again in three different segments, one for each world. The first visualization was just meant to acquaint the informant with the whole plot; the segmented visualization was used for linguistic production, so the informant was asked to tell a listener what he had just seen after each segment. The question he/ she was asked was: "what have you just seen?". The listener did not know the film, so the task was based on a lack of shared knowledge.

We transcribed the narrations according to the CHAT parameters (Codes for the Human Analysis of Transcripts - MacWhinney, 2000).

The informants who took part in the investigation are divided into three groups: two reference groups formed of Italian and English native speakers; a group of Italian learners of L2 English. Each group is composed of 16 informants. The Italian reference group comes from the Naples area; 11 out of 16 have a university degree, the others have a high school diploma. For the English L1 group, almost all of them are American and work for the US Navy or the NATO (North Atlantic Treaty Organization) base in Naples; all but one have a university degree. Among the learners, only three of them do not have a university diploma. For all learners, the C1 level of the Common European Framework of Reference for Languages (CEFR) was ascertained by appropriate written and oral texts.

\section{Analysis of the native data}

\subsection{Subordination and clause embedding}

Subordinate constructions play a relevant role in both groups of native data but they are used more frequently in Italian retellings. The following table gives information about the independent or subordinate character of clauses (finite and non finite) with respect to the background or foreground of narrations.

\begin{tabular}{|l|l|l|r|r|}
\cline { 2 - 5 } \multicolumn{1}{c|}{} & $\begin{array}{l}\text { Main clauses } \\
\text { (foreground) }\end{array}$ & $\begin{array}{l}\text { Main clauses } \\
\text { (background) }\end{array}$ & $\begin{array}{l}\text { Subordinates } \\
\text { (foreground) }\end{array}$ & $\begin{array}{l}\text { Subordinates } \\
\text { (background) }\end{array}$ \\
\hline English L1 & $371(28.08 \%)$ & $422(31.94 \%)$ & $29(2.19 \%)$ & $481(36.41 \%)$ \\
\hline Italian L1 & $441(32.42 \%)$ & $297(\mathbf{2 1 . 8 3 \% )}$ & $56(4.11 \%)$ & $607(44.63 \%)$ \\
\hline
\end{tabular}

Table 1 - English and Italian L1s:

main and subordinate clauses in foreground vs. background 
The most crucial differences between the two groups of narrations concern main and subordinate clauses in the background: English native speakers often employ main clauses in this informational domain (31.94\%), for which Italian informants prefer subordinates $(44.63 \%)$. As a result, the percentages of main vs. subordinate clauses in the background are very close to each other for English $(31.94 \% \mathrm{~m} . \mathrm{cl}$. vs. $36.41 \%$ sub. cl.), but considerably different for Italian $(21.83 \%$ m. cl. vs. $44.63 \%$ sub. cl.). Generally speaking, Italian speakers mark the organization of information through subordination more frequently, since subordinates ( $48.08 \%$ out of the total number of propositions) are almost as frequent as main clauses; subordinates are not lacking in English retellings but they amount to 38\% (out of the total number of propositions).

Table 2 details the types of subordination ${ }^{11}$.

The most remarkable difference between the two groups of retellings lies in the higher percentages of (explicit) relative clauses in Italian. Consequently, in Italian, relativizing seems to play a more crucial role when packaging information for narrations, which is strengthened by the fact that this type of subordination accounts for the highest percentage of subordinate clauses $(43.27 \%$, followed by completive object clauses with $16.81 \%$ ).

Table 3 gives information about clause embedding (whether it is recursive or not) for each reference group, distinguishing between different degrees of embedding ( 2 clauses $>3$ clauses $>4$ and + clauses). For this purpose we excluded the parts of retellings concerned with the introduction and conclusion of the video proposed, since they do not present dynamic interweaved events, and considered just the adventures in the three worlds of the story (the paper world, the stone world and the machine world). Here are some passages concerned with embedding and recursion (recursive relative clauses):

[3] English L1, 7 clauses

1. and I think

2. this this is the part

3. he gets miner too

4. 'cause he picks up a rock

5. to break the ground

6. to get to the water

7. instead of using his hands
Main Clause, $B G$

Object, $B G$

Relative, $B G$

Cause, $B G$

Purpose, $B G$

Purpose, $B G$

Aversion, $B G$

11. The acronym CVC stands for complex verb constructions. Specifically in this study, it refers to the periphrasis try to + Infinitive, for which we assume the existence of two processes - 1.try + 2.to Vlexical - with the infinitive having a purpose function. Note that the percentages in table 2 were calculated based on the total of subordinates. 


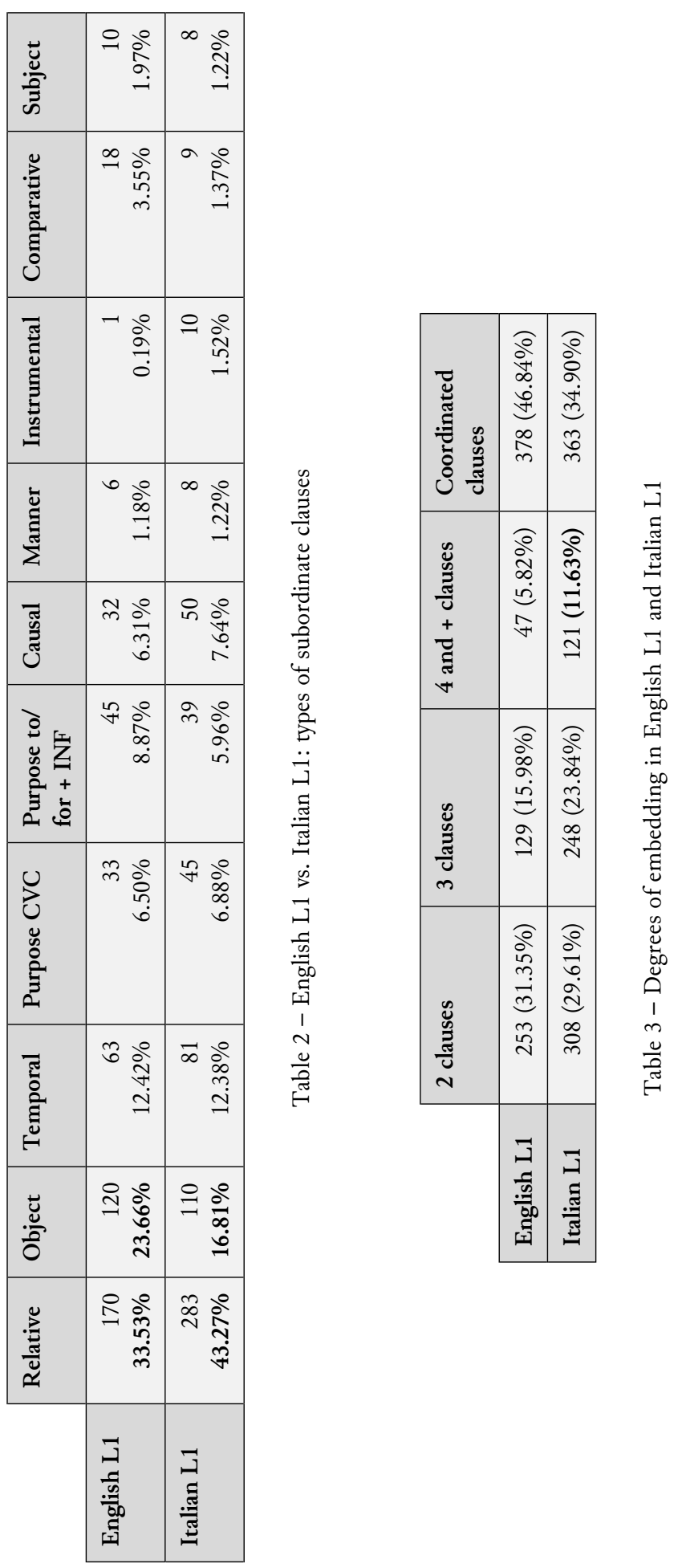


[4] Italian L1, relative recursion

1. ora si trova in un secondo ambiente

Main Clause, $B G$ 'now he finds himself in a second environment'

2. sempre un ambiente dove c'è mancanza di vegetazione di: Relative, $B G$ acqua di qualsiasi cosa

'still an environment where there's lack of vegetation of water of anything'

3. che però è hm \# hm ricoperto da tanti fogli di carta 'which nevertheless is $\mathrm{hm}$ \# covered with many sheets of paper'

4. che il vento stesso rimuove $[\ldots]$

Relative, $B G$ 'that the wind itself removes'

[5] Italian L1, 7 clauses

1. hm [poiché é] sempre attirato dal rumore dell'acqua Cause Implicit, $B G$ 'hm [since he is] always attracted by the noise of water'

2. continua la propria ricerca 'he continues his own search'

3. fino al momento in cui: riesce non più a sentire la goccia Time, $B G$ d'acqua 'up to the moment when he manages not to hear the drop of water [any more]'

4. che cade 'which falls'

5. bensì [riesce] a vedere hm: a vedere l'acqua e: 'but [he manages] to see hm: to see the water e:'

6. anche se la vede per poco 'even though he sees it for a short moment'

Main Clause, FG

perché poi viene tutto oscurato dall'introduzione di una Cause, BG grata

'because then everything is made obscure by a grate'

As table 3 shows, 3 and 4+ clause embeddings are more frequent in Italian than in English retellings; in particular, the percentage of deep embedding (4+ embedding) by the Italian speakers (11.63\%) is double that of English native informants $(5.82 \%)$. This result demonstrates, along with the massive use of subordination in general, that bierarchizing is cognitively more prominent in Italian narrations than in English ones.

Furthermore, Italian narrations seem to involve a more frequent combination of non finite and finite clauses in $4+$ clause hierarchizing ( 9 contexts). The non finite constructions correspond to a Participio Passato with a relative function (cf. attirato in [5] above; conficcata in [6] below) and a temporal Gerundio (cf. immaginando in [7] below). 
[6] Italian L1
1. dopo essersi alzato 'after getting up'
Temporal, $B G$
2. si accorge
Main Clause, FG
'he realized'
3. di avere una scheggia di una pietra 'to have a rock splinter'
4. conficcata in una mano 'stuck in one hand'
Object, $B G$
Relative, $B G$

[7] Italian L1
1. e quindi comincia a scavarecon un masso 'and so [he] starts digging with a rock'
2. per cercare di: di: pre:n/ di trovarla 'to try to: to get to / to find'
3. immaginando 'imagining'
Main Clause, FG
Purpose, BG
Temporal, $B G$
4. che si trovi sul sotto la superficie 'that [it] is on under the surface'
Object, $B G$

Though rarer, the combination of finite and non finite clauses is of course possible in English as well. The most frequent non finite verb form, namely the -ing form, shows up in 2 and 3 clause embeddings (and just in one 4+ clause context) and takes on a relative function (as we shall see in part 5.2, Adverbial and Past Participles are very rare in English narrations):

[8] English L1

1. and uh then he saw the papers Main Clause, $F G$

2. flying around Relative, $B G$

[9] English L1

1. whilst he's on the stone column Temporal, $B G$

2. he can ah he finds the water droplets ahm Main Clause, $F G$

3. falling onto the the stone floor ahm Relative, $B G$

For both languages under study, however, finite clauses are more often combined - in any type of embedding - with less condensed constructions than the ones seen above, namely with to + root Infinitive and di/per + Infinito having object or purpose functions and coreferential with respect to the preceding main clause (for English, cf. to get to the water instead of using his hands in [3]; for Italian, cf. per cercare di trovarla in [7] and di avere una scheggia di una pietra in [6]).

As the examples altogether demonstrate, different types of semantic and logical relations can be hierarchized. 


\subsection{Non finite subordination and condensation}

All types of non finite clauses correspond to a way of synthetizing information, namely the one concerned with finiteness (person, tense, aspect and modality), which can be seen as condensing linguistic complexity (cf. part 2). With respect to the two languages under study, their native speakers exploit non finite constructions in slightly different percentages: in English $15.38 \%$ of subordinate clauses are non finite; in Italian the percentage drops to $10.55 \%$. The two groups employ similar means but with a very different frequency: in Italian the Participio Passato forms play a crucial role as non finite clause (40 occ.: $57.97 \%$ out of the total 69 ), followed by the Gerundio (27 occ.: $39.13 \%$ out of the total), whereas there is just one occurrence of the Participio Presente, proveniente, a surviving form ${ }^{12}$. The unique Participio Presente acts as a relative clause; the Gerundio covers several adverbial functions (time 9 occ., cause 9 occ., instrument 4 occ., manner 3 occ., consecutive 2 occ.); as for the Participio Passato, we have identified relative (3 occ.), causal (3 occ.) and temporal (1 occ.) values. Here are some examples:

[10] Italian L1, Participio Passato with relative function

$$
\text { un mondo fatto di pietre Relative, } B G
$$

'a world [which is] made of stone'

[11] Italian L1, Participio Passato with temporal function
1. una volta arrivata sul fondo hm
Temporal, $B G$ 'once arrived to the bottom hm'
Main Clause, FG
2. la sabbia si solidifica di nuovo 'the sand solidifies'

[12] Italian L1, causal Gerundio

1. i fogli di carta [...] essendo umidi Causal, BG 'the sheets of paper [...] being humid = since they are humid'
2. si aprono 'open up'
Main Clause, FG

In English the percentages of the several non finite clauses are almost reversed with respect to the Italian types: the most frequently exploited non finite constructions are with the $V$-ing form, 52 of which act as relative clauses $(66.66 \%)$ out of the total (78) and 18 as -ing Adverbial Participle (23.07\%); only 10 non finite clauses are formed with Past Participles (12.82\%) ${ }^{13}$. Moreover, differently from the Italian Participio Passato, the English -ed Participle takes on only a relative function; concerning the -ing Adverbial Participle the most frequent function

12. In contemporary Italian most forms of Participio Presente have taken on an adjectival function.

13. Our results about spoken English Participles are to some extent in agreement with the different frequencies ascertained by Granger (1997) for -ed and -ing Participles in written academic English. 
is the temporal one (8 occ.), followed by instrument ( 2 occ.), manner ( 2 occ.), consecutive $(2$ occ.), condition (1 occ.) and causal (1 occ.). Some examples:

[13] English L1, -ed Participle with relative function

1. I compared it to Stonehenge among all these stones Main Clause, $B G$

2. all piled up Relative, $B G$

[14] English L1, -ing Adverbial Participle with temporal function

1. it's not getting: not getting any easier with him Main Clause, $B G$

2. going further Temporal, $B G$

As a general result, we can state that non finite constructions show up in narrations of both groups of native speakers but with some relevant differences with respect to the non finite forms selected and their functions ${ }^{14}$.

\section{The L2 data analysis}

As for the native speakers, we analyzed the correlation between the type of clause selected (main or subordinate) and the foreground vs. background of narrations. As table 4 shows, learners prefer main clauses for the events of the foreground (36.2\%) and subordinates for background information (31.2\%).

Nevertheless, similarly to English native speakers (cf. table 1), the difference between main clauses and subordinate clauses in the background is minimal (0.2\%), which could be interpreted as the learners' ability to master one of the preferential modalities of packaging information in English.

As for the types of subordinates, our analysis demonstrates that learners massively exploit relative clauses with respect to other types of clauses (cf. table 5), a result that can evidently be compared to the one obtained for Italian native retellings (cf. table 2).

Still concerning relative clauses, learners employ them both with finite (44\%) and non finite verbs (37\%). The latter percentage shows that they have perceived the crucial role fulfilled by implicit $V$-ing clauses in English ${ }^{15}$. The massive use of explicit relative clauses, conversely, suggests that learners continue to adopt the typical Italian modality of hierarchizing information in narrative (cf. part 5.2.), despite their high interlanguage level in L2 (C1). As far as the other types of subordinates are concerned, table 5 below illustrates percentages of employment very comparable to those noted for the native speakers of both groups.

14. We ascertained the coreference of the subject of the Gerundio and -ing Participle clause with that of the main clause for both groups of narrations.

15. Granger (1997) reports a similar result for written academic English of L2 learners having Dutch, French and Swedish as L2s, which could mean that the English postmodifying Participle is more easily learned than other types. 

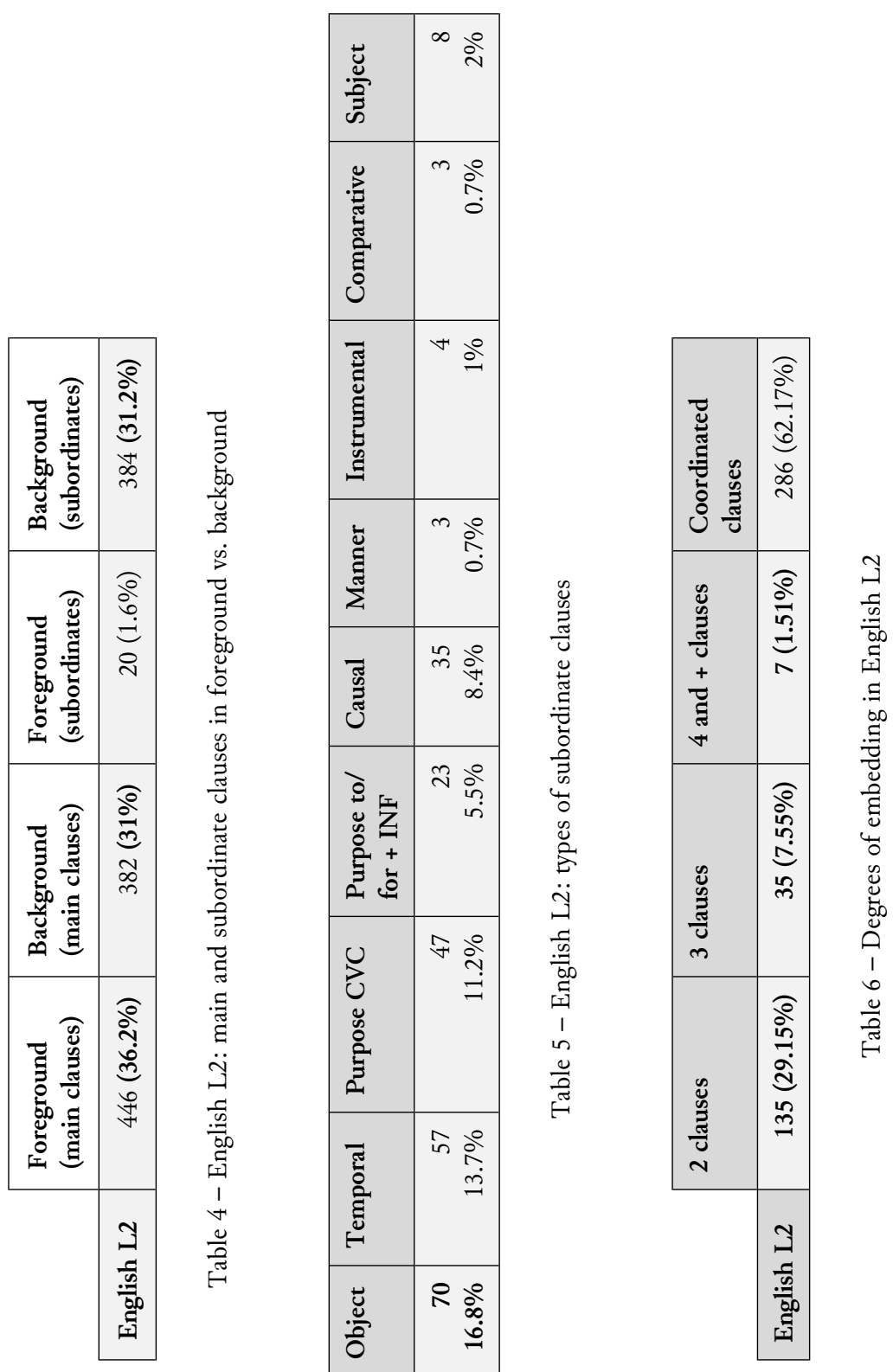
As for the type of clause embedding (cf. table 6), we remind the reader that we only analyzed the passages regarding the dynamic adventures of the three worlds (paper, stones, machines) involved in the task.

Table 6 shows that learners of English L2, similarly to native speakers of Italian and English, mostly exploit the 2 clause embedding (29.15\%; cf. [15]) and much less frequently the 3 and $4+$ clause embeddings $(7.55 \%$ and $1.51 \%$, respectively; cf. [16] and [17]):

[15] English L2, 2 clauses

1. while he's near this paper Temporal, $B G$

2. he produces a big hole Main Clause, FG

[16] English L2, 3 clauses

1. he reaches the point Main Clause, $F G$

2. where he thinks Relative, $B G$

3. there's water Object, $B G$

[17] English L2, 4 clauses

1. as he starts to $\mathrm{XX}$ trying to enlarge this this hole Temporal, $B G$

2. ehm as soon as he starts to do that Temporal, $B G$

3. he realizes Main Clause, $F G$

4. that he is actually into a metal press like the one Object, $B G$

5. that they use in for car wrecking sort of places Comparative, $B G$

The massive exploitation of the 2 clause embedding may appear to indicate an approach to the L2 perspective. Nevertheless, it is also possible to hypothesize a process of simplification that is typical of interlanguage dynamics.

It is necessary to observe that the most frequent non finite morphology concerns the Past Participle (26 occ.; cf. made in [18]), a reminiscence, once again, of the L1 perspective; the -ing form is, conversely, used in a more marginal way (14 occ.; cf. falling in [19]).

[18] English L2, 4 clauses

1. In this other scene we see the man Main Clause, $B G$

2. made of sand Relative, $B G$

3. who has arrived in a world Relative, $B G$

4. made of paper of: sheets of paper Relative, $B G$

[19] English L2, 2 clauses

1. and even in this scenario he: he he finds he finds the same Main Clause, $F G$ water drops

2. falling on on the ground Relative, $B G$ 
Similarly to what was ascertained for English L1 narrations, in the learners' retellings the -ed Participles all concern the relative function and the -ing Participial forms can take on different adverbial meanings (temporal and manner, 5 occ.).

Finally, similarly to native speakers, learners often combine a finite clause with a non finite one.

\section{Discussion}

\subsection{Cognitive and typological implications of our results}

The analysis that we carried out on our narrative data in English and Italian as L1s have led to some typological and cognitive considerations, that we will comment on by going back to the research questions (RQs) stated in part 4.1:

1. which types of morpho-syntactic structures - main or subordinated, finite or non finite - are exploited to convey the subordinated contents selected?

2. which type of semantic and/or logical components (temporality, causality...; subject, object..., relative) are selected to be narrated and highlighted through subordination?

3. do the informants tend to hierarchize the subordinated contents expressed?

Concerning RQ1 and RQ3, our results lead us to state that subordination is much more frequent in Italian than in English (approximately 10\% more), but that native speakers of both languages extensively exploit both finite and non finite constructions. For Italian, the greater employment of subordinate clauses goes along with an iconic deeper embedding (but not necessarily recursion) of the expressed contents: as a result, we can state that for Italian speakers bierarchizing is cognitively more prominent than for English native speakers. This state of affairs seems to confirm what we proposed in part 2, namely that deep embedding - even though ascertained to be heavier to process from a cognitive viewpoint - can be favored in languages with a rich verb morphology such as Italian. So, a core morphological feature of this language seems to lead to a structural result, which in turn could be further favored by a pragmatic reason: the Italian enunciator (unconsciously) knows that deep embedding is less risky for communicative purposes because of the repetition of information about finiteness conveyed by each (or most) verb form(s) in a hierarchical structure. The greater transparency of Italian finite forms and Participi Passati could also explain the more frequent alternation of finite and non finite clauses in embeddings by native speakers of this language.

Regarding the type of relations expressed in subordination (RQ2), the differences between the two languages under study uniquely concern their frequencies and not really their semantics and logic/argument structure ${ }^{16}$ (cf. table 2).

16. For temporal clauses, nevertheless, it should be noted that Engl. when clauses always correspond to cases of true focalization of a time span, differently from It. quando clauses which are also exploited to create suspense (in correlation with all'improvviso: "suddenly") and to give examples. 
Other results can be highlighted for condensation and non finite clauses (RQ1), whose percentages and formal modalities vary according to the language (cf. part 5.2). Subordinated non finite contents are more recurrent in English narrations ( $4.83 \%$ more) than in the Italian ones, although subordination on the whole is less frequent in the former. If we consider that, in English retellings, the high percentage of main clauses goes along with a strict juxtaposition as a privileged way of packaging information both in the foreground and background of narrations (cf. Giuliano \& Anastasio, in press for this point), we obtain a very special way of retelling facts. Native speakers of English are structurally simpler in their manner of expressing contents (coordination and juxtaposition are the preferred means to organize them) and have slightly more frequent recourse to condensed information than Italian speakers, which gives support to the idea by Giuliano and Anastasio (in press) that English narrations are in some ways more implicit and that because of that, they involve more tortuous inferential processes by the co-enunciator. Obviously, the weak morphology of English grammar cannot explain this state of things: since morphology conspires against transparency, the speaker should tend to be as clear as possible and not implicit. Here we have a core grammatical feature, the weak morphology, that seems to explain the recourse to some less complex structures (less deep embedding), but not the lower percentage of subordination in general, nor the more frequent exploitation of non finite clauses. We maintain that the grammar of a language does not necessarily justify all the observable textual mechanisms. The latter can be significantly influenced and shaped by peculiar pragmatic and cultural babits such as the more or less explicit way of conveying information (cf. quotations in part 2 by Gumperz and Levinson [1996] and the results by Giuliano and Di Maio [2007] for descriptions in English). We wish to suggest that iconicity and economy are processes rooted in different discourse and interactional practices across cultures.

To conclude, we think that both core grammatical features and enunciative orientations along with cultural habits interact with each other in a specific community, and that all three can be responsible for a certain cognitive and linguistic way of conceiving and packaging information, narrative or other.

\subsection{Implications for second language acquisition and indications for future studies in the learning domain}

In the second section of this work we focused on the morpho-syntactic complexity detected in the Quest retellings by a group of Italian learners of English L2, that have a $\mathrm{C} 1$ interlanguage level (cf. part 4.2.). As before, we shall try to answer the RQs exposed in part 4.1. with respect to these informants.

Concerning the morpho-syntactic structures employed (RQ1), our analysis shows that learners of English prefer main clauses for the events of foreground and subordinates to enrich the narration in the background (36.2\% vs. $31.2 \%$ respectively), a tendency that we ascertained for the Italian native group as well. Nevertheless, the unimportant difference $(0.2 \%)$ between independent and subordinate clauses 
in the background is comparable to the tendency observed for the English native speakers. As for non finite clauses, the participial -ed forms win over the -ing forms, and among the latter the -ing Adverbial Participle is in a minority ${ }^{17}$, which is definitively in contrast with the tendency observed for English native data, but very much in agreement with the results of the Italian L1 group. Learners also tend to hierarchize information through relative clauses (RQ2), a result which is very similar to what we established for the Italian L1 data (38.6\% for Italian L2 vs. $43.27 \%$ for Italian L1). As for the other types of subordinate clauses, the tendencies ascertained are very comparable to the ones commented on for the two native groups: object clauses are the most frequent after relative clauses, whereas all the other types are much rarer (RQ3).

Still concerning RQ3, the analysis of clause embedding ( 2 clauses $>3$ clauses $>$ $4+$ clauses) is particularly interesting in our English L2 retellings because of the acquisitional implications that they seem to involve. Similarly to the reference groups, learners mostly select 2 clause embeddings; the percentages for higher embeddings are insignificant. At first glance, this minimal grade of embedding seems to approach the target language perspective and, as a consequence, to reflect a departure from the linguistic habits of the L1. But we can wonder whether this way of hierarchizing information is due to an interlanguage process of simplification, responding to the exigency of a minimally efficient communication (cf. the "prototypical treatment" described by Perdue, 1993; Watorek, 1996).

As a general conclusion, we can state that advanced learners adopt a perspective that is "mixed" with respect to the languages involved, demonstrating that they are incapable of completely departing from the L 1 perspective but equally incapable of completely absorbing that of the L2 (cf. also infra).

The analysis of our learner data leads us to ponder over the didactic implications of the morpho-syntactic phenomena observed with respect to speakers whose L1 system is relevantly different from the target one. Italian L1 learners of English should realize - conceptually, first, and linguistically second - that they have to downplay continual hierarchizing (recursive or not) in favor of coordination and juxtaposition as preferential means of organizing information in L2, which, at least theoretically, could turn out to be cognitively simpler for a learner coming from more complex discourse patterns. We can also speculate on English L1 subjects learning Italian, for whom the exact reverse process should be true: they have to detect the more complex way of hierarchizing information in Italian with respect to the one they are used to in their mother tongue, in which coordination is preferred. In other words, they have to realize, conceptually and linguistically, that bierarchizing is cognitively more prominent for Italian speakers than for English ones. Consequently, learners of Italian should mostly select relative clauses, and among the non finite relative type, they should realize that the Participio Passato is the only

17. Granger (1997) reports a similar result for her written L2 data in Academic English. 
one exploited in Italian. By doing so, they would abandon the L1-ing form with a relative function, whose corresponding Italian form - the Participio Presente - has almost completely disappeared.

In acquisitional terms, our results point out a continual contradiction that is typical of advanced learners: at first glance, the latter may seem to be close (and sometimes even very close) to the conceptual and linguistic preferences of the L2 (cf., for our Italian learners of English, the appropriate employment of the -ing non finite clauses), but at a deeper level they are still affected by the typological features and textual perspective of their L1 (cf. the relevant use of relativization, the preference for -ed Participle clauses over -ing clauses). These results are in line with those of other studies on adult second language acquisition (cf. Carroll \& Stutterheim, 2003; Carroll \& Lambert, 2006; Carroll et al., 2008b; Anastasio, 2019) including some work focussing on both conceptual and enunciative habits (cf. Giuliano \& Di Maio, 2007; Giuliano, 2012; Giuliano \& Musto, 2016, 2018; Giuliano \& Anastasio, in press). In the present study, we have tried to make the reader sensitive to the fact that the grammar of a language cannot explain everything if we broaden our outlook from the sentence to the textual dimension: here, typological, conceptual and enunciative habits interweave with one another with respect to a culturally specific community, making the observable facts very problematic for the analyst.

Since our learners acquired English in an institutional environment, we can wonder about the teaching and learning of the morpho-syntactic structures investigated in our study together with the accompanying conceptual and enunciative implications: in particular, how can one help learners grasp some very subtle aspects of the structural categories in question, for instance, the less transparent inferential processes that they involve and the less deep embedding? The answer to this question is not an easy one. Teachers should prompt learners to reflect more on the form-function relationships (for ex. the -ing form/function) with respect not simply to the clause or sentence level but also and significantly to the textual level (foreground vs. background). The focus on the varied form/function relationships within a specific textual genre could bring learners to grasp aspects of the L2 that normally escape their attention. Pragmatic and enunciative habits - important facets in the actual use of any conceptual and linguistic category - should in general be better detected (by researchers first, and by teachers second) and become part of the taught contents, by giving the learner concrete and more frequent examples of L2 input, namely of the real usage of a language. This way of working can help the elaboration of linguistic categories (e.g., morpho-syntactic ones) with respect to the $\mathrm{L} 2$ way of thinking and being.

To translate the acquisitional results of a study into didactic applications is not easy, even though in both domains (acquisition and didactics) the learner is the center of interest. It is necessary to create a real interface between these two subdomains, as some authors have already tried to do (cf. Véronique, 2017; Watorek et al., in press). For this same purpose, Rastelli (2009) proposed a new conception of didactics by adopting the expression "acquisitional didactics", whose aim is to 
develop didactic patterns to use in the classroom in agreement with the results emerging from second language acquisition studies. Much is still to be done in order for this interface to be created but nowadays, luckily, research seems to be going in this direction.

\subsection{Conclusion}

During this research we focused on the subordinated modalities of organizing and packaging information in an oral narrative task in English and Italian L1 and in English L2. In the functional acquisitional framework of analysis, studies of this type are lacking since narrations have been studied from a conceptual point of view (which conceptual domains are highlighted by narrators in a specific language?) rather than a syntactic and enunciative perspective (cf. Carroll \& Stutterheim, 2003; Carroll \& Lambert, 2006; Carroll et al., 2008a and b).

Our results suggest that, even though finite and non finite constructions are used by both native groups, some important differences have to be taken into account. First, the employment of subordinate clauses and syntactic hierarchizing seems to be greater in Italian than in English, probably because of the rich verb morphology of the former. Second, the conceptual level - namely, the semantic contents involved - does not seem instead so different between the two languages in question. Third, English narrations are more implicit than Italian ones in how information is expressed, not only because of the weak morphology of English but also due to different modalities of conceiving interaction, in which the co-enunciator often has to make a greater interpretative effort because of the referentially implicit way in which the English enunciator conceives the information flow. We therefore contend that grammars cannot always exhaustively explain the observable textual mechanisms, which can also be shaped by enunciative and cultural habits, as other - albeit very few - studies have demonstrated in recent years with respect to both narrative and descriptive texts (cf. Giuliano \& Di Maio, 2007; Giuliano \& Musto, 2016, 2018). The study of textual patterns should be combined with a strict observation of the interactional habits through which these patterns are exploited in a given community, since (cognitive) linguistic operations seem to be molded and shaped by these habits as well. It is not a coincidence that the American anthropologist and linguist Paul Frederich, already in the last century, defined linguistic relativity as rooted in human discourse. An approach combining grammatical, textual and enunciative demands, such as ours, is not an easy one of course, given the tangled way in which the several determining factors subtending human communication interact with one another.

As for the non native data, our results show that the Italian advanced learners of English L2 tend to adopt a mixed perspective in narration. On the one hand, they are still influenced by the typological and textual L1 perspective (for example the preference for Participio Passato clauses over -ing clauses); on the other hand, they seem to match the target language perspective with regards to the use of the -ing non finite clauses and the less complex clause embedding. Nevertheless, for the 
latter point we also wonder if this way of hierarchizing information reflects the minimal prototypical treatment of the task (Perdue, 1993; Watorek, 1996). If this is the case, our learners are not adopting the L2 perspective but rather exploiting a syntactic and communicative strategy representative of the developmental trajectory of L2 learners in general.

Lastly, and only tangentially, we pondered how teachers could facilitate the acquisition of the narrative morpho-syntactic structures for English L2 learners, but we are aware that much has still to be done in order to create an appropriate interface between second language acquisition and learning.

\section{References}

AdAm, J.-M. 1981. Labov et le récit. Cabiers de linguistique sociale 3: 4-129.

ADAM, J.-M. 1997. Une alternative au “tout narratif”: les gradients de narrativité. Recherches en communication 7: 11-35. DOI: https://doi.org/10.14428/rec.v7i7.46393

Adamczewski, H. 2002. The Secret Architecture of English Grammar. Précy-sur-Oise: Éditions EMA.

Adamczewski, H. \& Gabilan, J.-P. 1993. Les clés de la grammaire anglaise. Paris: A. Colin.

Anastasio, S. 2019. L'expression du déplacement en italien L2. Perspectives typologiques et psycholinguistiques. Language, Interaction and Acquisition 10 (2): 204-228. DOI: https://doi.org/10.1075/lia.19003.ana

Carroll, M. \& Lambert, M. 2006. Reorganizing Principles of Information Structure in Advanced L2s: French and German Learners of English. In H. Byrnes, H. WegerGuntharp \& K.A. Sprang (eds.), Educating for Advanced Foreign Language Capacities: Constructs, Curriculum, Instruction, Assessment. Washington: Georgetown University Press: 54-73.

Carroll, M., Natale, S. \& Starren, M. 2008a. Acquisition du marquage du progressif par des apprenants germanophones de l'italien et néerlandophones du français. AILEAcquisition et interaction en langue étrangère 26: 31-50. DOI: https://doi.org/10.4000/ aile. 2942

Carroll, M., Rossdeutscher, A., Lambert, M. \& Stutterheim, C. von 2008b. Subordination in Narratives and Macro-Structural Planning: A Comparative Point of View. In C. Fabricius-Hansen \& W. Ramm (eds.), "Subordination" versus "Coordination" in Sentence and Text: A Cross-Linguistic Perspective. Amsterdam - Philadelphia: J. Benjamins: 161-184. DOI: https://doi.org/10.1075/slcs.98.09car

Carroll, M. \& Stutterheim, C. von 2003. Typology and Information Organisation: Perspective Taking and Language-Specific Effects in the Construal of Events. In A. Giacalone Ramat (ed.), Typology and Second Language Acquisition. Berlin New York: De Gruyter: 365-402. DOI: https://doi.org/10.1515/9783110891249.365

Chini, M. 2003. Aspetti della competenza testuale di apprendenti tedescofoni avanzati di italiano L2: scelte grammaticali e organizzazione dell'informazione. In R. BомBI \& F. Fusco (ed.), Parallela 10. Sguardi reciproci. Vicende linguistiche e culturali dell'area italofona e germanofona. Udine: Forum Edizioni: 221-246. 
Chini, M. 2005. Reference to Person in Learner Discourse. In H. Hendriks (ed.), The Structure of Learner Varieties. Berlin - New York: De Gruyter: 65-110. DOI: https:// doi.org/10.1515/9783110909593.65

Chini, M. 2008. Spunti comparativi sulla testualità nell'italiano L2 di tedescofoni e ispanofoni. In G. Bernini, L. Spreafico \& A. VAlentini (eds.), Competenze lessicali e discursive nell'acquisizione di lingue seconde. Perugia: Guerra Edizioni: 301-339.

Cristofaro, S. 2003. Subordination. Oxford Studies in Typology and Linguistic Theory. Oxford - New York: Oxford University Press.

Culioli, A. 1995. Cognition and Representation in Linguistic Theory. Amsterdam Philadelphia: J. Benjamins. DOI: https://doi.org/10.1075/cilt.112

Giuliano, P. 2012. Contrasted and Maintained Information in a Narrative Task: Analysis of Texts in English and Italian as L1s and L2s. EUROSLA Yearbook 12 (1): 30-62. DOI: https://doi.org/10.1075/eurosla.12.04giu

Giuliano, P. 2013. Comparaison de phénomènes complexes en italien et en français chez des adolescents bilingues et monolingues: focus sur le texte narratif. Travaux de linguistique 66: 73-96. DOI: https://doi.org/10.3917/tl.066.0073

Giuliano, P. \& Anastasio, S. in press. The Italian and English Perspectives in Narrations: Evidence from Retellings of Native Speakers and L2 Learners. SILTA - Studi italiani di linguistica teorica e applicata 50 (2).

Giuliano, P. \& Di Maio, L. 2007. Abilità descrittiva e coesione testuale in L1 e L2: lingue romanze e lingue germaniche a confronto. Linguistica e filologia 25: 125-205. DOI: http://dx.doi.org/10.6092/LeF_25_p125

Giuliano, P. \& Musto, S. 2016. Assertive Strategies in English and Spanish: A New Contribution to the Debate on Assertion in Romance and Germanic Languages. Testi e linguaggi 10: 237-252.

Giuliano, P. \& Musto, S. 2018. The Construction of Textual Cohesion in Spanish and Italian, as Mother Tongues and as Second Languages. Lingue e linguaggi 26: 235-257. DOI: https://doi.org/10.1285/i22390359v26p235

Givón, T. 1995. Functionalism and Grammar. Amsterdam - Philadelphia: J. Benjamins. DOI: https://doi.org/10.1075/z.74

Givón, T. \& Shibatani, M. (eds.) 2009. Syntactic Complexity. Diacbrony, Acquisition, Neuro-Cognition, Evolution. Amsterdam - Philadelphia: J. Benjamins. DOI: https:// doi.org/10.1075/tsl.85

Granger, C. 1997. On Identifying the Syntactic and Discourse Features of Participle Clauses in Academic English: Native and Non-Native Writers Compared. In J. AarTs, I. de Mönnink \& H. Wekker (eds.), Studies in English Language and Teaching: In Honour of Flor Aarts. Amsterdam - Atlanta: Rodopi: 185-198.

GumPerZ, J.J. \& Levinson, S.C. (eds.) 1996. Retbinking Linguistic Relativity. Studies in the Social and Cultural Foundations of Language 17. Cambridge: Cambridge University Press.

Havu, E. \& Pierrard, M. 2012. Prédication seconde et subordination: à propos du degré de complexité de la connexion de prédications. In U. PAProckA-Piotrowska, C. Martinot \& S. Gerolimich (eds.), La complexité en langue et son acquisition. Lublin: Towarzystwo Naukowe KUL: 37-51. 
Klein, W. 2006. On Finiteness. In V. Van Geenhoven (ed.), Semantics in Acquisition. Dordrecht: Springer: 245-272.

KleIn, W. \& LI, P. (eds.) 2009. The Expression of Time. Berlin - New York: De Gruyter. DOI: https://doi.org/10.1515/9783110199031

Klein, W. \& Stutterheim, C. von 1991. Text Structure and Referential Movement. Sprache und Pragmatik 22: 1-32.

Labov, W. 1972. The Transformation of Experience in Narrative Syntax. In W. Labov, Language in the Inner City: Studies in the Black English Vernacular. Philadelphia: University of Pennsylvania Press: 354-396.

Labov, W. 1997. Some Further Steps in Narrative Analysis. Journal of Narrative and Life History 7 (1-4): 395-415. DOI: https://doi.org/10.1075/jnlh.7.49som

MacWhinney, B. 2000. The CHILDES Project: Tools for Analyzing Talk. Mahwah - London: L. Erlbaum [3rd ed.].

Musto, S. 2018. Temporalità e organizzazione del discorso in italiano e in spagnolo. Lingua materna e lingua seconda a confronto. Bern: P. Lang.

Natale, S. 2013. Linkage in Narratives: A Comparison between Monolingual Speakers of French and Italian, and Early and Late French-Italian Bilinguals. IRAL - International Review of Applied Linguistics in Language Teaching 51 (2): 151-169. DOI: https://doi. org/10.1515/iral-2013-0007

Perdue, C. 1993. Comment rendre compte de la "logique" de l'acquisition d'une langue étrangère par l'adulte. Études de linguistique appliquée 92: 8-22.

Propp, V.I. 1968. Morphology of the Folktale. L. ScotT (trans.). Austin: University of Texas Press [2nd ed.]. [Russian ed. 1928: Morfologija skazki].

Quirk, R., Greenbaum, S., Leech, G. \& Svartvik, J. 1985. A Comprehensive Grammar of the English Language. London - New York: Longman.

Rastelli, S. 2009. Che cos'è la didattica acquisizionale. Roma: Carocci Editore.

SLOBIN, D.I. 1991. Learning to Think for Speaking: Native Language, Cognition, and Rhetorical Style. Pragmatics 1 (1): 7-25. DOI: https://doi.org/10.1075/prag.1.1.01slo

SLOBIN, D.I. 1996. From "Thought and Language" to "Thinking for Speaking”. In J.J. Gumperz \& S.C. Levinson (eds.), Retbinking Linguistic Relativity. Studies in the Social and Cultural Foundations of Language 17. Cambridge: Cambridge University Press: 70-96.

SLOBIN, D.I. 2003. Language and Thought Online: Cognitive Consequences of Linguistic Relativity. In D. GENTNER \& S. Goldin-MEAdow (eds.), Language in Mind: Advances in the Study of Language and Thought. Cambridge - London: MIT Press: 157-192.

Stutterheim, C. von \& Klein, W. 1989. Referential Movement in Descriptive and Narrative Discourse. In R. Dietrich \& C.F. Graumann (eds.), Language Processing in Social Context. North-Holland Linguistic Series: Linguistic Variations 54. Amsterdam: Elsevier Science Publishers: 39-76. DOI: https://doi.org/10.1016/B978-0-444-87144-2.50005-7

VÉRONIQUE, G.D. 2017. Réponse à Wander Lowie: l'émergentisme, la recherche sur l'acquisition des langues et la didactique des langues étrangères. Recherches en didactique des langues et des cultures. Les cabiers de l'Acedle 14 (1). DOI: https://doi.org/10.4000/rdlc.1385 
Watorek, M. 1996. Le traitement prototypique: définition et implications. Toegepaste Taalwetenschap in Artikelen 55 (1): 187-200. DOI: https://doi.org/10.1075/ttwia.55.15wat

Watorek, M., Arslangul, A. \& Rast, R. (eds.) in press. Premières étapes dans l'acquisition des langues étrangères: dialogue entre acquisition et didactique des langues. Paris: Presses de l'Inalco. 